\title{
L-Type Voltage-Gated Calcium Channels in the Basolateral Amygdala Are Necessary for Fear Extinction
}

\author{
Stephanie E. Davis and Elizabeth P. Bauer \\ Biology Department and Neuroscience and Behavior Program, Barnard College, New York, New York 10027
}

L-type voltage-gated calcium channels (L-VGCCs) in the basolateral nucleus of the amygdala (BLA) are necessary for long-term memory of fear conditioning, where they are thought to drive the activation of protein kinases and to initiate gene transcription. However, their role in fear extinction learning is unclear given that systemic injections of VGCC antagonists induce a protracted stress response. Here we tested the effects of local infusions of the L-VGCC antagonists verapamil and nifedipine on both within-session extinction and fear extinction consolidation. Intra-BLA infusions of verapamil or nifedipine did not affect the expression of fear conditioning or the amount of within-session extinction but impaired extinction memory when rats were tested $24 \mathrm{~h}$ later drug-free. L-VGCC antagonists also prevented the increase in phosphorylated mitogen-activated protein kinase (MAPK) normally seen in the BLA following extinction learning. These results suggest that activation of L-VGCCs in the BLA at the time of fear extinction learning is necessary for the long-term retention of fear extinction via the MAPK pathway.

\section{Introduction}

The molecular mechanisms underlying fear extinction have important clinical implications for the treatment of several psychiatric disorders such as posttraumatic stress disorder and phobias (Bouton et al., 2001; Milad et al., 2006). Extinction of conditioned fear is a form of new learning in which a conditioned stimulus (CS) previously associated with an unconditioned stimulus (US) is repeatedly presented alone so that it ceases to elicit a fear response (Myers and Davis, 2002; Maren and Quirk, 2004). The original fear memory is inhibited, but not erased, as extinction actively suppresses fear responses in a context-dependent fashion (Maren and Quirk, 2004). Evidence suggests that the basolateral nucleus of the amygdala (BLA) is a critical site of plasticity required for the acquisition and storage of extinction memory (Quirk and Mueller, 2008; Pape and Pare, 2010). Indeed, disrupting plasticity in the BLA before extinction training by blocking NMDA receptors or the mitogen-activated protein kinase (MAPK), PI-3 kinase and SRC kinase pathways within the BLA impair the acquisition of fear extinction (Lu et al., 2001; Bevilaqua et al., 2003; Lin et al., 2003; Herry et al., 2006; Sotres-Bayon et al., 2007).

L-type voltage-gated calcium channels (L-VGCCs) play a well known role in synaptic plasticity, where they are thought to link activity at the neuronal membrane with gene transcription in the nucleus (Grover and Teyler, 1990; Dolmetsch et al., 2001; Thomas and Huganir, 2004). Within the BLA, they are necessary for the acquisition of Pavlovian auditory fear conditioning (Bauer et al., 2002). The role of L-VGCCs in fear extinction, however, is more controversial since conflicting results of their involvement have been obtained (Schafe, 2008). Systemic injec-

Received Feb. 20, 2012; revised Aug. 7, 2012; accepted Aug. 8, 2012.

Author contributions: E.P.B. designed research; S.E.D. and E.P.B. performed research; S.E.D. and E.P.B. analyzed data; E.P.B. wrote the paper.

Correspondence should be addressed to Elizabeth Bauer, Biology Department, Barnard College, 3009 Broadway, New York, NY 10027. E-mail: ebauer@barnard.edu.

DOI:10.1523/JNEUROSCI.0809-12.2012

Copyright $\odot 2012$ the authors $\quad 0270-6474 / 12 / 3213582-05 \$ 15.00 / 0$ tions of L-VGCC antagonists do not affect fear conditioning, but do impair fear extinction (Cain et al., 2002). Systemic injections of these antagonists also produce a protracted stress response, however, mediated by peripheral L-VGCCs (Busquet et al., 2008; Waltereit et al., 2008), suggesting that the role of L-VGCCs should be assessed via local infusions rather than systemic injections. The amygdala contains two L-VGCC isoforms: $\mathrm{Ca}_{\mathrm{V}} 1.2$ and $\mathrm{Ca}_{\mathrm{V}} 1.3$ (Hetzenauer et al., 2006). While $\mathrm{Ca}_{\mathrm{V}} 1.3$ is critical for contextual fear conditioning, mice with forebrain deletions of either $\mathrm{Ca}_{\mathrm{V}} 1.2$ or $\mathrm{Ca}_{\mathrm{V}} 1.3$ show no impairment of contextual fear extinction (McKinney and Murphy, 2006; McKinney et al., 2008). The involvement of these two isoforms in auditory fear conditioning and extinction has not been explored.

Unfortunately, the only pharmacological studies to assess the role of L-VGCCs in fear extinction have used systemic rather than local injections (Cain et al., 2002; McKinney et al., 2008). Here, we used intra-BLA infusions of the L-VGCC antagonists verapamil and nifedipine before fear extinction learning to test the involvement of these channels on fear memory expression and fear extinction consolidation. Our results suggest that L-VGCCs within the BLA are necessary for fear extinction, and that their blockade prevents the phosphorylation of MAPK normally seen in the BLA following fear extinction learning.

\section{Materials and Methods}

Subjects. Adult male Sprague Dawley rats (Charles River Laboratories; 275-325 g) were housed individually with ad libitum access to food and water and maintained on a $12 \mathrm{~h}$ light/dark cycle. All procedures were conducted in accordance with the National Institutes of Health Guide for the Care and Use of Laboratory Animals and were approved by Columbia University's Animal Care and Use Committee.

Surgery. Rats were anesthetized with a mixture of isoflurane and oxygen and mounted in a stereotaxic apparatus. Betadine was applied to the scalp and a local anesthetic (bupivacaine) was injected under the scalp. The scalp was incised and small burr holes were made in the skull above the BLA ( $-2.8 \mathrm{AP}, \pm 5.3 \mathrm{ML}$; Paxinos and Watson, 1998). Guide cannulas (26 gauge; Plastics One) were inserted just dorsal to the BLA ( -6.0 
DV) and cemented, with skull screws, to the skull. Dummy cannulas were inserted to prevent clogging. Rats received an analgesic (carprofen, 5 $\mathrm{mg} / \mathrm{kg}$, i.p.) and $5 \mathrm{ml}$ of lactated Ringer's (s.c.). Animals recovered for 1 week before behavioral testing.

Behavior. At $24 \mathrm{~h}$ after habituation to the training context, rats were placed in a rodent conditioning chamber with a metal grid floor (Context A; Coulbourn Instruments). Rats received 3 tone-shock pairings: $\mathrm{CS}=2 \mathrm{kHz}$ tone, $30 \mathrm{~s}$; US $=0.5 \mathrm{~mA}$ shock, $1 \mathrm{~s}$, tone coterminating with the shock. Then, $24 \mathrm{~h}$ later, rats were placed in a different context (B) with a black Plexiglas floor washed with peppermint soap. They received 10 CS tones (30 s duration; 60-120 s intertone intervals). Then, $24 \mathrm{~h}$ later, to test extinction recall, rats were placed in context $\mathrm{B}$ and again received $10 \mathrm{CS}$ tones. Time spent freezing to each CS (immobility with the exception of breathing) was manually scored for each animal. At the end of behavioral experiments, animals were killed by carbon dioxide inhalation, their brains removed and stored in $4 \%$ paraformaldehyde in $0.1 \mathrm{~m}$ phosphate buffer (PB). Brains were sectioned at a thickness of $100 \mu \mathrm{m}$. Nissl staining and light microscopy were used to verify cannula placements within the amygdala. Only behavioral data from animals with accurate cannula placements were analyzed.

Infusions. At 15 min before extinction learning, animals received bilateral intra-BLA infusions of vehicle (artificial CSF, ACSF; $0.5 \mu \mathrm{l}$ ) or verapamil dissolved in ACSF (low dose $=1 \mu \mathrm{g} / \mathrm{side}$; high dose $=5 \mu \mathrm{g} / \mathrm{side}$ in $0.5 \mu \mathrm{l})((-)$-Verapamil hydrochloride hydrate; Sigma-Aldrich) or infusions of vehicle [ $50 \%$ saline, $50 \%$ dimethyl sulfoxide (DMSO), $0.5 \mu \mathrm{l}$ ] or nifedipine dissolved in $50 \%$ saline, $50 \%$ DMSO $(8 \mu \mathrm{g} / \mathrm{side}$ in $0.5 \mu \mathrm{l}$; Sigma-Aldrich). Animals were infused at a rate of $1 \mu \mathrm{l} / \mathrm{min}$ and the infusion cannulas (extending $2 \mathrm{~mm}$ from the guide cannulas) were left in place for 1-2 min to allow drug diffusion away from the tip.

Immunohistochemistry. Separate groups of rats received surgery, as above, underwent fear conditioning, infusions of ACSF or the high dose of verapamil $(5 \mu \mathrm{g} /$ side in $0.5 \mu \mathrm{l}$ ) and fear extinction with $10 \mathrm{CS}$ tones as above. One group of animals received infusions of ACSF and then 1 CS tone to reactivate the fear memory without extinguishing fear. Forty-five minutes after the final tone, rats were deeply anesthetized with Euthasol (containing pentobarbital; $100 \mathrm{mg} / \mathrm{kg}$, i.p.) and perfused with $0.9 \%$ saline followed by $4 \%$ paraformaldehyde in $0.1 \mathrm{M} \mathrm{PB}$. Brains were removed and postfixed for $24 \mathrm{~h}$. Coronal sections $(50 \mu \mathrm{m})$ were cut on a vibratome and every other slice was collected. Sections were treated with $1.8 \% \mathrm{H}_{2} \mathrm{O}_{2}$ for 5 min to reduce endogenous peroxidase activity, and then washed in PBT $(0.1 \mathrm{M}$ PB with $1 \%$ Triton X-100). Sections were blocked in $1 \%$ bovine serum albumin (in PBT) for $1 \mathrm{~h}$ and incubated at $4^{\circ} \mathrm{C}$ for $48 \mathrm{~h}$ in anti-phospho MAPK (pMAPK; 1:400) [Phospho-p44/42 MAPK (Erk1/2) (Thr202/Tyr204)] rabbit monoclonal antibody; Cell Signaling Technology). Slices were washed in PBT and incubated with biotinylated goat anti-rabbit (1:200; Vector Labs) for $1 \mathrm{~h}$ at room temperature. Slices were processed with avidin-biotin horseradish peroxidase complex (Vectastain ABC Kit, Vector Labs). Horseradish peroxidase was visualized with $3,3^{\prime}$ diaminobenzidine in a $3 \mathrm{~m}$ sodium acetate buffer containing $0.05 \%$ $\mathrm{H}_{2} \mathrm{O}_{2}$. Sections were washed, mounted on slides, and coverslipped. Using light microscopy, six slices per animal were examined, covering the entire rostro-caudal length of the BLA and central nucleus of the amygdala (CE). pMAPK-positive cells were counted manually with the aid of an optical grid. Because every other slice was collected, there was no need to correct for double-counting.

\section{Results}

We first examined the effects of intra-BLA injections of the L-VGCC antagonist verapamil on fear extinction. Rats were habituated to the training context on day 1 and conditioned with 3 tone-shock pairings on day 2 (Fig. $1 \mathrm{~A} ; \mathrm{CS}=2 \mathrm{kHz} 30 \mathrm{~s}$ tone coterminating with a footshock US $=0.5 \mathrm{~mA}, 1 \mathrm{~s}$ ). Postshock freezing was measured (Fig. $1 B)$. A repeated-measures ANOVA across all 3 groups showed no significant differences between groups $\left(F_{(2,21)}=0.649 ; p=0.53\right)$, insuring that there were no a priori differences between groups. Twenty-four hours later, rats received intra-BLA infusions of vehicle (ACSF; $n=10$ ) or one of two different doses of verapamil ( $1 \mu \mathrm{g}, n=$ 8 or $5 \mu \mathrm{g} /$ side, $n=6$ ). Fifteen minutes later, rats were placed in context $\mathrm{B}$ and presented with $10 \mathrm{CS}$ tones (Fig. 1C). A repeated- measures ANOVA across all 3 groups showed no effect of drug $\left(F_{(2,21)}=0.061 ; p=0.94\right)$. However, $24 \mathrm{~h}$ later, rats previously treated with the highest dose of verapamil showed impairment of long-term memory of fear extinction (Fig. 1D). A repeatedmeasures ANOVA found a significant effect of group $\left(F_{(2,21)}=4.97\right.$; $p<0.05)$. Tukey's post hoc $t$ tests revealed that significant differences existed between vehicle controls and the highest dose of verapamil (5 $\mu \mathrm{g} /$ side; $p<0.05$ ).

The above data suggest that long-term retention of fear extinction is disrupted by intra-BLA infusion of L-VGCC antagonists. However, it is well known that verapamil can interfere with other VGCCs such as the P- and Q-subtypes (Ishibashi et al., 1995; Dobrev et al., 1999) as well as with potassium channels (Waldegger et al., 1999 ) and $\alpha$-adrenergic receptors (Müller and Noack, 1988). We therefore repeated the above experiments using the more specific L-VGCC antagonist and dihydropyridine drug nifedipine.

Rats were habituated to the training context on day 1 and conditioned with 3 tone-shock pairings on day 2 as above, and postshock freezing was measured (Fig. $1 E$ ). A repeated-measures ANOVA showed no significant differences between groups $\left(F_{(1,21)}=0.14 ; p=0.71\right)$. Then, $24 \mathrm{~h}$ later, rats received intra-BLA infusions of vehicle (50\% saline, $50 \%$ DMSO; $n=9$ ) or nifedipine ( $8 \mu \mathrm{g}$ per side dissolved in $0.5 \mu \mathrm{l}$ of vehicle; $n=14$ ). Fifteen minutes later, rats were placed in context $B$ and presented with 10 CS tones (Fig. $1 F$ ). A repeated-measures ANOVA between the two groups across all 10 tones showed no effect of drug $\left(F_{(1,21)}=\right.$ $0.231 ; p=0.64)$. However, $24 \mathrm{~h}$ later, rats previously treated with nifedipine showed impairment of long-term memory of fear extinction (Fig. 1G). A repeated-measures ANOVA found a significant effect of group $\left(F_{(1,21)}=4.69 ; p<0.05\right)$. Animals injected with the highest dose of verapamil appeared to be insensitive to the reextinction trials given on testing day (Fig. $1 D$ ). This phenomenon was not seen with the lowest dose of verapamil nor with nifedipine, however. Together, these behavioral data suggest that while the expression of fear memory is not dependent on L-VGCCs in the BLA, long-term retention of fear extinction is disrupted by intra-BLA infusion of L-VGCC antagonists.

Given the fact that L-VGCC antagonists can have acute anxiolytic properties (Matsumoto et al., 1994; El Ganouni et al., 1998), we were concerned that impaired expression of freezing itself on extinction training day would cause enhanced freezing during testing day. We therefore performed an additional analysis in which nifedipine animals were divided into two subgroups: those that exhibited low freezing to the first tone on extinction training day, and those that exhibited high freezing to the first tone. If an impairment in fear extinction learning is due solely to reduced freezing during extinction training day, then "low freezing" animals should show increased freezing (impaired learning) during recall day, but "high freezing" animals should not. However, there was no difference between the two subgroups in their percentage freezing to the first tone on extinction recall day (Fig. $1 H)$, as confirmed by a Student's $t$ test $(p=0.91)$.

In the second group of experiments, we investigated whether fear extinction leads to an increase in PMAPK in the BLA, and whether this increase can be prevented by infusion of L-VGCC antagonists. Rats were habituated to the training context and fear conditioned with 3 tone-shock pairings. On day 3, one group of animals received intra-BLA infusions of vehicle ACSF $15 \mathrm{~min}$ before fear extinction learning (10 CS tones). A second group received intra-BLA infusions of the highest dose of verapamil (5 $\mu \mathrm{g} /$ side) $15 \mathrm{~min}$ before fear extinction learning (10 CS tones). A third group received intra-BLA infusions of ACSF 15 min before 

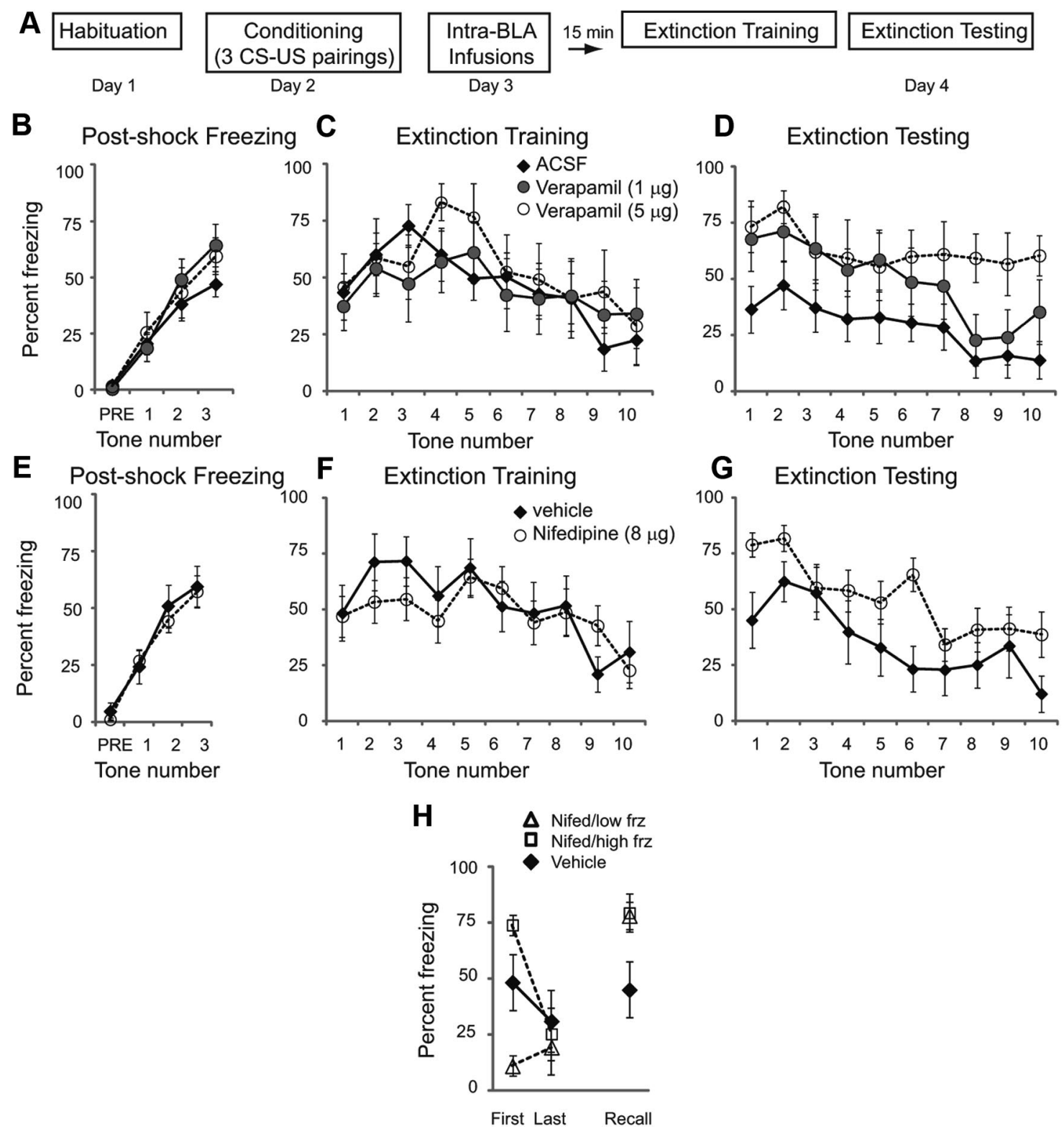

Figure 1. L-VGCC antagonists in the BLA impair long-term memory of fear extinction. $A$, Schematic of behavioral protocol. $B$, Mean \pm SE postshock freezing after three conditioning trials. $C$, Mean \pm SE percentage freezing to 10 CS tones $24 \mathrm{~h}$ after training in rats given intra-BLA infusions of ACSF $(n=10), 1 \mu \mathrm{g}$ of verapamil $(n=8)$, or $5 \mu \mathrm{g}$ of verapamil ( $n=6) 15$ min before testing. $D$, Mean \pm SE percentage freezing to $10 C S$ tones $24 \mathrm{~h}$ after extinction training, drug-free. $E$, Mean \pm SE postshock freezing. $F$, Mean \pm SE percentage freezing to $10 C S$ tones $24 \mathrm{~h}$ after training in rats given intra-BLA infusions of $50 \%$ saline, $50 \%$ DMSO vehicle $(n=9)$ or $8 \mu$ of nifedipine $(n=14) 15$ min before testing. G, Mean \pm SE percentage freezing to $10 \mathrm{CS}$ tones $24 \mathrm{~h}$ after extinction training, drug-free. $\boldsymbol{H}$, Rats receiving nifedipine were divided into low and high freezing subgroups (Nifed/low frz, $n=6$; Nifed/high frz, $n=8$ ) based on their percentage freezing to the first tone on extinction training day. Average freezing is compared between these and the vehicle group for freezing to the first and last tones on training day and the first tone on extinction testing day.

receiving 1 CS tone, to reactivate the fear memory without extinction (Fig. $2 A ; n=4$ for each of the three groups).

In animals receiving intra-BLA infusions of ACSF followed by extinction training, we observed pMAPK labeling throughout the BLA and CE 45 min after the end of training (Fig. 2B,C). However, in animals receiving intra-BLA infusions of ACSF followed by exposure to $1 \mathrm{CS}$, to reactivate the fear memory without extinction, there was a significant reduction of pMAPK labeling in the BLA $(p<0.0001$, Student's $t$ test $)$. The number of pMAPKlabeled cells in the CE was not significantly different following reactivation $(p>0.05)$. To test whether increases in pMAPK in the BLA following fear extinction learning are dependent on L-VGCCs, one group of animals received intra-BLA infusions of verapamil ( $5 \mu \mathrm{g} / \mathrm{side}$ ) before extinction. A one-way ANOVA of the three BLA groups (extinction, reactivation and verapamil- infused) showed a significant effect $(p<0.0001)$, with Tukey's post hoc tests showing a significant difference between the extinction group versus the reactivation group $(p<0.0001)$ and the extinction group versus the verapamil group $(p<0.0001)$. There was no significant difference between the reactivation group and the verapamil group ( $p=0.37$ ). Example images containing the BLA and CE show pMAPK-labeled cells for each of the three groups (Fig. $2 D-G$ ). Together, these results suggest that L-VGCCs in the BLA are necessary for the formation of long-term fear extinction memory via phosphorylation of MAPK.

\section{Discussion}

In this study, we evaluated the role of L-VGCCs within the BLA in the acquisition and consolidation of long-term fear extinction memories. Our findings indicate that blockade of these channels during 


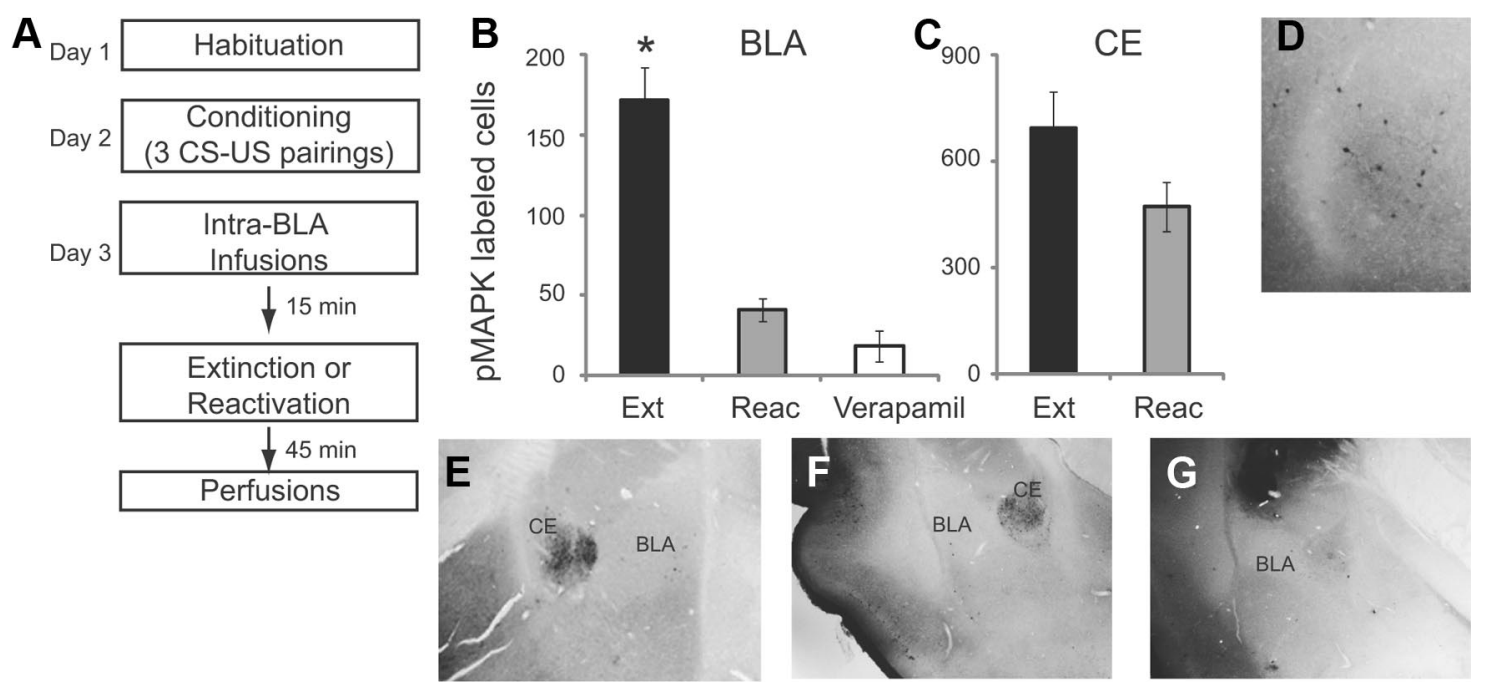

Figure 2. Extinction training induces pMAPK in the BLA which is blocked by intra-BLA infusions of verapamil. $\boldsymbol{A}$, Schematic of behavioral protocol. $\boldsymbol{B}$, Number of pMAPK-labeled cells in the BLA after ACSF infusion followed by extinction (Ext) or reactivation (Reac) or verapamil infusion followed by extinction (Verapamil). C, Number of pMAPK-labeled cells in the CE after ACSF infusion followed by extinction (Ext) or reactivation (Reac). $\boldsymbol{D}$ - G, Example images showing pMAPK-labeled cells at high magnification in the BLA (D), following ACSF extinction $(\boldsymbol{E})$, ACSF reactivation $(\boldsymbol{F})$ and Verapamil extinction (G).

fear extinction has no effect on the expression of fear conditioning or the amount of within-session extinction. However, when fear extinction memory was assessed $24 \mathrm{~h}$ later drug-free, animals who had received intra-BLA infusions of L-VGCC antagonists showed impaired fear extinction memory. This suggests that activation of these channels in the BLA at the time of learning is necessary for the consolidation of long-term fear extinction memories.

Previous research has suggested that these channels play a role in extinction (Cain et al., 2002). However, the interpretation of these studies is complicated by the fact that systemic injections of L-VGCC antagonists decrease locomotor activity and rearing for up to $4 \mathrm{~h}$ after injections and simultaneously produce a significant increase in plasma corticosterone levels (Waltereit et al., 2008). This "state" appears to be sufficiently aversive as to act as a US during contextual conditioning, lasting well after the compound has left the CNS (McKinney et al., 2008). However, this protracted stress response appears to be mediated by peripheral VGCCs, since it is not produced by intraventricular injections (Busquet et al., 2008). Here, by using local intra-BLA infusions, we circumvented this problem. Indeed, the absence of any effect of the drug on the day of infusions argues against this drug having a nonspecific effect on locomotor activity when infused directly into the BLA.

Interestingly, intracerebroventricular or systemic injections of L-VGCC antagonists can have anxiolytic properties (Matsumoto et al., 1994; El Ganouni et al., 1998) which have been previously reflected as an acute reduction in fear during fear extinction training (Busquet et al., 2008). This short-term anxiolytic effect was not apparent following intra-BLA injections of either verapamil or nifedipine, suggesting that these compounds exert their anxiolytic effect outside the BLA. Both the bed nucleus of the stria terminalis (BNST) and CE contain L-VGCCs (Cole et al., 2005) and play a critical role in anxiety and fear expression (Walker and Davis, 2008). Thus, while L-VGCCs within the BLA may be critical for fear conditioning and extinction, their effects on anxiety may occur outside the BLA.

Animals treated with L-VGCC antagonists showed enhanced freezing during testing day to the first CS tone compared with both the postshock period and the first CS tone during extinction training day. We observed this effect with both verapamil and nifedipine.
One possible explanation for this result relies on the fact that extinction involves not only the formation of a new memory, but weakening of the original CS-US association (Pape and Pare, 2010). Moreover, fear extinction may involve activation and/or plasticity of inhibitory circuits within the amygdala (Chhatwal et al., 2005; Likhtik et al., 2008). Given that pMAPK can upregulate presynaptic GABA release and the expression of $\mathrm{GABA}_{\mathrm{A}}$ receptor subunits in the cortex and cerebellum (Xie et al., 2004; Matsumoto et al., 2006), it is possible that one consequence of inhibiting the L-VGCC-pMAPK pathway would be to decrease GABAergic inhibition in the amygdala. This might be manifested by increased freezing during extinction recall, although this possibility remains to be tested.

In the second experiment, the distribution of pMAPK within the BLA and CE was examined following fear extinction learning. In agreement with a previous study, pMAPK was upregulated in the BLA 45 min after fear extinction learning (Herry et al., 2006). Although the time course of pMAPK activation was not evaluated in this study, it is well documented that there is a clear peak in pMAPK activity in the BLA 60 min following fear conditioning (Schafe et al., 2000) and fear extinction learning (Herry et al., 2006) but not at $15 \mathrm{~min}$ or $2 \mathrm{~h}$. Because our extinction protocol was longer than either of these fear conditioning or fear extinction protocols, we shortened the time between the end of extinction and perfusion to $45 \mathrm{~min}$. Surprisingly, there was much greater pMAPK staining in the CE, with pMAPK visible in both the lateral and medial nuclei of the CE. To disambiguate whether pMAPK was upregulated in these nuclei in response to fear extinction learning, or to fear reactivation, a separate group of animals underwent fear conditioning and then were exposed to one CS tone to reactivate the fear memory but without extinction. In these animals, there was significantly less pMAPK staining in the BLA but a similar amount of staining in the CE. This result suggests that fear reactivation leads to phosphorylation of MAPK in the CE, but not in the BLA and that animals must undergo extinction learning for pMAPK upregulation in the BLA. We then tested how intra-BLA infusions of verapamil before fear extinction learning affect pMAPK levels in the BLA. At the dose that impairs extinction learning, verapamil also prevented the phosphorylation of MAPK in the BLA. 
Our results are in line with previous research showing that calcium influx through L-VGCCs is particularly effective at initiating phosphorylation of MAPK and CRE-mediated transcription (Dolmetsch et al., 2001; Thomas and Huganir, 2004). Nevertheless, additional second-messenger pathways may be activated via calcium influx through L-VGCCs. For example, calcium ions rapidly bind to calmodulin near the ion channel following VGCC activation, and calmodulin can itself then translocate to the nucleus (Deisseroth et al., 1998; Dolmetsch et al., 2001). L-VGCCs could also activate CaMKII or the PI-3 kinase pathway (Lin et al., 2003; Yasuda et al., 2003). Furthermore, calcium influx through NMDA receptors can also contribute to phosphorylation of MAPK (English and Sweatt, 1996; Hardingham et al., 2001). Given that NMDA receptor activation within the BLA is crucial for fear extinction (Sotres-Bayon et al., 2007), the precise contributions of these two sources of calcium to the activation of second-messenger pathways should be further explored. Thus, additional research will be needed to determine the mechanism by which L-VGCCs activate the MAPK pathway in the BLA and whether PMAPK drives gene expression in the BLA following extinction learning.

\section{References}

Bauer EP, Schafe GE, LeDoux JE (2002) NMDA receptors and L-type voltage-gated calcium channels contribute to long-term potentiation and different components of fear memory formation in the lateral amygdala. J Neurosci 22:5239-5249. Medline

Bevilaqua LR, Rossato JI, Medina JH, Izquierdo I, Cammarota M (2003) Src kinase activity is required for avoidance memory formation and recall. Behav Pharmacol 14:649-652. CrossRef Medline

Bouton ME, Mineka S, Barlow DH (2001) A modern learning theory perspective on the etiology of panic disorder. Psychol Rev 108:4-32. CrossRef Medline

Busquet P, Hetzenauer A, Sinnegger-Brauns MJ, Striessnig J, Singewald N (2008) Role of L-type $\mathrm{Ca}^{2+}$ channel isoforms in the extinction of conditioned fear. Learn Mem 15:378-386. CrossRef Medline

Cain CK, Blouin AM, Barad M (2002) L-type voltage-gated calcium channels are required for extinction, but not for acquisition or expression, of conditional fear in mice. J Neurosci 22:9113-9121. Medline

Chhatwal JP, Myers KM, Ressler KJ, Davis M (2005) Regulation of gephyrin and GABAA receptor binding within the amygdala after fear conditioning and extinction. J Neurosci 25:502-506. CrossRef Medline

Cole RL, Lechner SM, Williams ME, Prodanovich P, Bleicher L, Varney MA, Gu G (2005) Differential distribution of voltage-gated calcium channel alpha-2 delta subunit mRNA-containing cells in the rat central nervous system and the dorsal root ganglia. J Comp Neurol 491:246-269. CrossRef Medline

Deisseroth K, Heish EK, Tsien RW (1998) Translocation of calmodulin to the nucleus supports CREB phosphorylation in hippocampal neurons. Nature 392:198-202.

Dobrev D, Milde AS, Andreas K, Ravens U (1999) The effects of verapamil and diltiazem on N-, P- and Q-type calcium channels mediating dopamine release in rat striatum. Br J Pharmacol 127:576-582. CrossRef Medline

Dolmetsch RE, Pajvani U, Fife K, Spotts JM, Greenberg ME (2001) Signaling to the nucleus by an L-type calcium channel-calmodulin complex through the MAP kinase pathway. Science 294:333-339. CrossRef Medline

El Ganouni S, Tazi A, Hakkou F (1998) Potential serotonergic interactions with the anxiolytic-like effects of calcium channel antagonists. Pharmacol Biochem Behav 60:365-369. CrossRef Medline

English JD, Sweatt JD (1996) Activation of p42 mitogen-activated protein kinase in hippocampal long-term potentiation. J Biol Chem 271:24329-24332. CrossRef Medline

Grover LM, Teyler TJ (1990) Two components of long-term potentiation induced by different patterns of afferent activation. Nature 347:477-479. CrossRef Medline

Hardingham GE, Arnold FJ, Bading H (2001) A calcium microdomain near NMDA receptors: on switch for ERK-dependent synapse-to-nucleus communication. Nat Neurosci 4:565-566.

Herry C, Trifilieff P, Micheau J, Lüthi A, Mons N (2006) Extinction of auditory fear conditioning requires MAPK/ERK activation in the basolateral amygdala. Eur J Neurosci 24:261-269. CrossRef Medline
Hetzenauer A, Sinnegger-Brauns MJ, Striessnig J, Singewald N (2006) Brain activation pattern induced by stimulation of L-type $\mathrm{Ca}^{2+}$-channels: contribution of $\mathrm{Ca}(\mathrm{V}) 1.3$ and $\mathrm{Ca}(\mathrm{V}) 1.2$ isoforms. Neuroscience 139:1005-1015. CrossRef Medline

Ishibashi H, Yatani A, Akaike N (1995) Block of P-type $\mathrm{Ca}^{2+}$ channels in freshly dissociated rat cerebellar Purkinje neurons by diltiazem and verapamil. Brain Res 695:88-91. CrossRef Medline

Likhtik E, Popa D, Apergis-Schoute J, Fidacaro GA, Paré D (2008) Amygdala intercalated neurons are required for expression of fear extinction. Nature 454:642-645. CrossRef Medline

Lin CH, Yeh SH, Lu HY, Gean PW (2003) The similarities and diversities of signal pathways leading to consolidation of conditioning and consolidation of extinction of fear memory. J Neurosci 23:8310-8317. Medline

Lu KT, Walker DL, Davis M (2001) Mitogen-activated protein kinase cascade in the basolateral nucleus of amygdala is involved in extinction of fear potentiated startle. J Neurosci 21:RC162(1-5). Medline

Maren S, Quirk GJ (2004) Neuronal signaling of fear memory. Nat Rev Neurosci 5:844-852. CrossRef Medline

Matsumoto T, Numakawa T, Yokomaku D, Adachi N, Yamagishi S, Numakawa Y, Kunugi $\mathrm{H}$, Taguchi $\mathrm{T}$ (2006) Brain-derived neurotropic factor-induced potentiation of glutamate and GABA release: different dependency on signaling pathways and neuronal activity. Mol Cell Neurosci 31:70-84. CrossRef Medline

Matsumoto Y, Kataoka Y, Watanabe Y, Miyazaki A, Taniyama K (1994) Antianxiety actions of calcium channel antagonists with Vogel-type conflict test in rats. Eur J Pharmacol 264:107-110. CrossRef Medline

McKinney BC, Murphy GG (2006) The L-Type voltage-gated calcium channel Cav1.3 mediates consolidation, but not extinction, of contextually conditioned fear in mice. Learn Mem 13:584-589. CrossRef Medline

McKinney BC, Sze W, White JA, Murphy GG (2008) L-type voltage-gated calcium channels in conditioned fear: a genetic and pharmacological analysis. Learn Mem 15:326-334. CrossRef Medline

Milad MR, Rauch SL, Pitman RK, Quirk GJ (2006) Fear extinction in rats: implications for human brain imaging and anxiety disorders. Biol Psychol 73:61-71. CrossRef Medline

Müller A, Noack E (1988) Additive competitive interaction of verapamil and quinidine at alpha-adrenergic receptors of isolated cardiac guinea pig myocytes and human platelets. Life Sci 42:667-677. CrossRef Medline

Myers KM, Davis M (2002) Behavioral and neural analysis of extinction. Neuron 36:567-584. CrossRef Medline

Pape HC, Pare D (2010) Plastic synaptic networks of the amygdala for the acquisition, expression, and extinction of conditioned fear. Physiol Rev 90:419-463. CrossRef Medline

Paxinos G, Watson C (1998) The rat brain in stereotaxic coordinates. San Diego: Academic.

Quirk GJ, Mueller D (2008) Neural mechanisms of extinction learning and retrieval. Neuropsychopharmacology 33:56-72. CrossRef Medline

Schafe GE (2008) Rethinking the role of L-type voltage-gated calcium channels in fear memory extinction. Learn Mem 15:324-325. CrossRef Medline

Schafe GE, Atkins CM, Swank MW, Bauer EP, Sweatt JD, LeDoux JE (2000) Activation of ERK/MAP kinase in the amygdala is required for memory consolidation of pavlovian fear conditioning. J Neurosci 20:8177-8187.

Sotres-Bayon F, Bush DE, LeDoux JE (2007) Acquisition of fear extinction requires activation of NR2B-containing NMDA receptors in the lateral amygdala. Neuropsychopharmacology 32:1929-1940. CrossRef Medline

Thomas GM, Huganir RL (2004) MAPK cascade signaling and synaptic plasticity. Nat Rev Neurosci 5:173-183. CrossRef Medline

Waldegger S, Niemeyer G, Mörike K, Wagner CA, Suessbrich H, Busch AE, Lang F, Eichelbaum M (1999) Effect of verapamil enantiomers and metabolites on cardiac $\mathrm{K}+$ channels expressed in Xenopus oocytes. Cell Physiol Biochem 9:81-89. CrossRef Medline

Walker DL, Davis M (2008) Role of the extended amygdala in shortduration versus sustained fear: a tribute to Dr. Lennart Heimer. Brain Struct Funct 213:29-42. CrossRef Medline

Waltereit R, Mannhardt S, Nescholta S, Maser-Gluth C, Bartsch D (2008) Selective and protracted effect of nifedipine on fear memory extinction correlates with induced stress response. Learn Mem 15:348-356. CrossRef Medline

Xie F, Raetzman LT, Siegel RE (2004) Neuregulin induces GABAA receptor beta2 subunit expression in cultured rat cerebellar granule neurons by activating multiple signaling pathways. J Neurochem 90:1521-1529. CrossRef Medline

Yasuda R, Sabatini BL, Svoboda K (2003) Plasticity of calcium channels in dendritic spines. Nat Neurosci 6:948-955. 